University of Nebraska - Lincoln

DigitalCommons@University of Nebraska - Lincoln

Faculty Publications, Classics and Religious

Studies Department

2009

Review of Kenneth Liberman, Dialectical Practice in Tibetan

Philosophical Culture: An Ethnomethodological Inquiry into

Formal Reasoning

Yaroslav Komarovski

University of Nebraska-Lincoln, ykomarovski2@unl.edu

Follow this and additional works at: https://digitalcommons.unl.edu/classicsfacpub

Part of the Classics Commons

Komarovski, Yaroslav, "Review of Kenneth Liberman, Dialectical Practice in Tibetan Philosophical Culture: An Ethnomethodological Inquiry into Formal Reasoning" (2009). Faculty Publications, Classics and Religious Studies Department. 76.

https://digitalcommons.unl.edu/classicsfacpub/76

This Article is brought to you for free and open access by the Classics and Religious Studies at DigitalCommons@University of Nebraska - Lincoln. It has been accepted for inclusion in Faculty Publications, Classics and Religious Studies Department by an authorized administrator of DigitalCommons@University of Nebraska - Lincoln. 
Forthcoming in Sophia: International Journal for Philosophy of Religion, Metaphysical Theology and Ethics [2010]; doi: 10.1007/s11841-009-0113-8

Copyright () 2009 Springer Science+Business Media B.V. Used by permission.

Published online July 25, 2009.

\title{
Review of Kenneth Liberman, Dialectical Practice in Tibetan Philosophical Culture: An Ethnomethodological Inquiry into Formal Reasoning
}

Lanham, MD: Rowman and Littlefield Publishers, 2007, ISBN: 978-0742556126, pb, 338pp.

\author{
Yaroslav Komarovski \\ University of Nebraska-Lincoln, Lincoln, NE, USA \\ Email ykomarovski@gmail.com
}

\begin{abstract}
Chapters 4-9 are the most important part of the book. Here Liberman displays his interpretive skills to the fullest. He explores various aspects of directly observed, live debate processes, drawing on the work of Schutz, Husserl, Durkheim (to mention just a few), as well as Buddhist thinkers Nagarjuna, Sakya Pandita, Tsongkhapa, and others. Liberman exhaustively explains the organization and mechanics of debates, the public nature of reasoning, negative dialectics employed by debaters, strategies and techniques such as absurd consequences, hand-claps, ridicule, and repetition, and other matters.
\end{abstract}

Keywords: philosophy, Buddhism, Tibetan culture, Buddhist dialectics, debate practices, ethnomethodology

Kenneth Liberman spent years studying, recording, and analyzing debates as they are practiced in actual life in Tibetan monastic institutions in exile. Liberman's first-hand exposure to Tibetan debate culture is remarkable, as is his ability to make that culture relevant and accessible to contemporary Euro-American scholars of philosophy and religion. The sympathetic and critical observation of live philosophical practices and the use of sociological interpretive strategies are two unquestionable strengths of the book.

Liberman contrasts his objective, "to gain intimate access to the local interactional practices that Tibetan philosophers use to provide for the orderliness of their philosophical inquiries" (32), with the approach of Tibetological studies that have "little to do with the actual interests of the people being studied," and are "essentially literary enterprises that work by fitting concepts together" (33). Thus, the first two chapters address numerous flaws of Orientalism and Tibetology, and 
propose an alternative "ethnomethodology," which Liberman describes as a minutely detailed study of "the actual praxis of Tibetan scholars" (34). He adopts this method not only because it allows one to study reasoning practices of Tibetan scholars as "phenomena in their own right," but also because "taking people seriously, and studying them in their own life-world, is an ethical way to treat research subjects" (39).

Chapter 3 surveys debate theories and practices as observed in contemporary Geluk monasteries, and can serve as a good introduction for readers not familiar with the topic. It discusses some technical vocabulary and ideas, provides a sketch of important debate theories and strategies, and contrasts debates as ideally conceived with debates as actually practiced in Tibetan monastic institutions.

Chapters 4-9 are the most important part of the book. Here Liberman displays his interpretive skills to the fullest. He explores various aspects of directly observed, live debate processes, drawing on the work of Schutz, Husserl, Durkheim (to mention just a few), as well as Buddhist thinkers Nagarjuna, Sakya Pandita, Tsongkhapa, and others. Liberman exhaustively explains the organization and mechanics of debates, the public nature of reasoning, negative dialectics employed by debaters, strategies and techniques such as absurd consequences, hand-claps, ridicule, and repetition, and other matters.

The author's primary objective is to describe and explain the practices of Tibetan debaters, not the philosophical topics on which they focus. As Liberman himself points out, "[s]ocial phenomenological studies, including ethnomethodological investigations, proceed not from a review of treatises but from an examination of the lived experience of persons" (31). One of the main strengths of the book is Liberman's ability to demonstrate and analyze in minute detail this very "lived experience."

Short video recordings of actual debates in Tibetan (available at the accompanying website http://www.thdl.org/DebateTutorials/) form an essential and inseparable part of the whole project. As the author argues, direct observation of the choreography of the Tibetans' debating is vital for an adequate understanding of technicalities of debates (47). The inclusion of those recordings also explains and partly compensates for the lack of vocabulary at the end of the book: readers who know Tibetan can figure out what terms are used while listening to and observing those recordings. It also can be seen as the author's attempt to push readers beyond the boundaries of reading words written on paper towards exposing themselves to listening and observing live processes of uttering those words and doing philosophy.

Despite its strengths, the book has two minor problems (pertaining mainly to the first two chapters): overly general criticism of "Tibetology" and "Tibetologists," and a tendency to limit Tibetan Buddhist philosophy to debate culture as practiced in several monastic institutions of the Geluk tradition.

In the first case, Liberman justly exposes the weaknesses of scholars who had or have little to no first hand exposure to Tibetan religious culture and colloquial Tibetan, and their involvement in colonialist-influenced discourse stemming from 19-th century Orientalist research that "commences with texts and not with people" (4). Nevertheless, his criticisms mostly fit an older generation of Buddhologists and Tibetologists, and then are superimposed on Tibetologists in general - a problematic move given the state of the field today. 
Liberman also tends to generalize as though Geluk-style debate practices are Tibetan Buddhist philosophy tout court. Although he mentions that his primary focus is the debate culture of the Geluk tradition, and admits that some monks of other traditions express negative opinions about debates $(47,63)$, he also states, for example, that "[i]n the Tibetan monastic universities philosophical debate is an everyday, all day long affair" (53). Such statements can hardly apply even to most Geluk institutions, not to mention institutions (including nunneries) of other traditions where, if practiced at all, debates play only a minor role. Furthermore, philosophical dimensions of different Tantric systems are rarely debated, and when they are, the number of institutions, debaters, and subjects debated is very limited, as in the case of Geluk tantric colleges, for example.

Liberman renders great service to those of us who are willing to step outside the boundaries of textual studies to join him in exploring actual Tibetan debate culture. His book is of definite benefit to both unprepared readers and those already familiar with Buddhist philosophy in general and Geluk philosophical culture in particular. Together with the accompanying Web site, parts of the book can also be adopted for advanced courses on Tibetan language, culture, and philosophy. Dialectical Practice in Tibetan Philosophical Culture not only brings more nuance and detail to our understanding of Tibetan philosophical practices; it opens altogether a new perspective on this exciting and important dimension of Buddhist culture in general. 